DOI:10.17951/h.2019.53.4.21-41

\begin{tabular}{lcc}
\hline \multicolumn{1}{c}{ A N N A L E S } \\
UNIVERSITATIS MARIAE CURIE-SKŁODOWSKA \\
LUBLIN - POLONIA \\
VOL. LIII, 4 & SECTIOH H \\
\hline
\end{tabular}

\title{
KRZYSZTOF BOROWSKI
}

krzysztof.borowski@sgh.waw.pl

Szkoła Główna Handlowa. Instytut Ryzyka i Rynków Finansowych

al. Niepodległości 162, 02-554 Warszawa, Polska

ORCID ID: https://orcid.org/0000-0003-0434-7573

\section{Efektywność i stabilność systemów transakcyjnych opartych na zwyktych, wykładniczo i liniowo ważonych średnich ruchomych}

Efficiency and Stability of Transaction Systems Based on Simple, Exponentially and Linearly Weighted Moving Averages

Keywords: moving averages; moving averages crossover; transaction systems; transaction system optimization; transaction systems stability

Słowa kluczowe: średnie ruchome; przecięcie średnich ruchomych; systemy transakcyjne; optymalizacja systemów transakcyjnych; stabilność systemów transakcyjnych

JEL: G14; G17

Propozycja cytowania: Borowski, K. (2019). Efektywność i stabilność systemów transakcyjnych opartych na zwykłych, wykładniczo i liniowo ważonych średnich ruchomych. Annales Universitatis Mariae Curie-Skłodowska, sectio H-Oeconomia, Vol. 53, No. 4.

\footnotetext{
Abstract

Theoretical background: Most papers are dedicated to the problem of optimizing transaction systems only for a single asset or index. In the literature there is a noticeable lack of comprehensive studies related to the entire group of assets.

Purpose of the article: Optimization of transaction systems based on the intersection of the moving average and the closing price (signal of purchase and sale) for 404 shares listed on the Warsaw Stock Exchange. For each equity, the survey covered 5,000 sessions or less if shares were traded in a shorter time horizon. The moving average types used in the study were: Simple Moving Average (SMA), Linearly Weighted Average
} 
(WMA) and Exponentially Weighed Average (EMA). In subsequent parts of the article, a ranking of moving averages was conducted and the stability of transactional systems was assessed.

Research methods: The following methods were used in the study: 1) moving averages optimizing the transaction system - correlation analysis of rates of return and of moving averages lengths, linear regression, 2) ranking of transaction system effectiveness - simple and weighted rates of return rankings, 3) analysis of transaction system stability - correlation of the first and second moving average lengths that bring the two highest rates of return, the determination factor for moving average pairs and rates of return, as well as the WF ratio (average decrease in the effectiveness of the 16 best transaction systems per unit rate of return of the best transaction system).

Main findings: The obtained results clearly indicate that for all types of averages, transaction systems were optimized in the vast majority by short-term averages, which confirms the investors' tendency to proceed transactions with a speculative rather than investment bias. Conducted ranking of the effectiveness of three types of moving averages (WMA, SMA, EMA) unambiguously indicated that for the most part the highest rates of return were obtained for transaction systems based on WMA, before SMA and EMA. The differences in the effectiveness of trading systems based on WMA and SMA were small, but systems using these two types of moving averages proved to be much more efficient than systems based on EMA.

\begin{abstract}
Abstrakt
Uzasadnienie teoretyczne: Większość artykułów dotyczy optymalizacji systemów transakcyjnych jedynie w odniesieniu do pojedynczego aktywu lub indeksu. W literaturze przedmiotu zauważalny jest brak opracowań kompleksowych dotyczących całej grupy aktywów.

Cel artykułu: Optymalizacja systemów transakcyjnych bazujących na przecięciu średniej ruchomej i ceny zamknięcia (sygnał kupna i sprzedaży) dla 404 akcji notowanych na Giełdzie Papierów Wartościowych w Warszawie. Dla każdego waloru badaniem objętych zostało 5000 sesji lub mniej, jeśli akcje były notowane w krótszym horyzoncie czasowym. Użytymi w badaniu rodzajami średnich były: zwykła średnia ruchoma (SMA), ważona liniowo (WMA) i ważona wykładniczo (EMA).W kolejnych częściach artykułu został przeprowadzony ranking średnich ruchomych oraz dokonano oceny stabilności systemów transakcyjnych. Metody badawcze: W opracowaniu zastosowano następujące metody: 1) średnie ruchome optymalizujące system transakcyjny - analiza korelacji stóp zwrotu i długości średnich ruchomych, regresja liniowa, 2) ranking skuteczności systemów transakcyjnych - rankingowanie proste i ważone stopą zwrotu, 3) analiza stabilności systemów transakcyjnych - korelacja długości pierwszej i drugiej średniej ruchomej, przynoszących najwyższe stopy zwrotu, współczynnik determinacji dla par średnich ruchomych i stóp zwrotu, a także współczynnik WF (średni spadek efektywności 16 najlepszych systemów transakcyjnych przypadający na jednostkową stopę zwrotu najlepszego systemu transakcyjnego).

Glówne wnioski: Otrzymane rezultaty jednoznacznie wskazują, że w przypadku wszystkich rodzajów średnich systemy transakcyjne były optymalizowane w przeważającej większości przez średnie krótkoterminowe, co potwierdza behawioralną skłonność inwestorów do zawierania transakcji raczej o zabarwieniu spekulacyjnym niż inwestycyjnym. Przeprowadzony ranking skuteczności trzech rodzajów średnich ruchomych (WMA, SMA, EMA) jednoznacznie wskazał, że w przeważającej części najwyższe stopy zwrotu były uzyskiwane przy zastosowaniu WMA, przed SMA i EMA. Różnice skuteczności systemów opartych o WMA i SMA były niewielkie, za to systemy bazujące na tych dwóch średnich ruchomych okazały się zdecydowanie bardziej efektywne od systemów wykorzystujących EMA.
\end{abstract}




\section{Wprowadzenie}

Średnie ruchome są wykorzystywane w analizie technicznej od lat 60 . XX w. (Keltner, 1960), chociaż ich korzenie sięgają 1901 r. (Raudys i Pabarskaite, 2018). Pierwotnie stosowano je w celu wyznaczenia momentu kupna i sprzedaży określonych aktywów. W przypadku gdy cena instrumentu przebijała średnią ruchomą od dołu w górę, powstawał sygnał kupna. Kiedy zaś cena przełamywała średnią w dół, generowany był sygnał sprzedaży (Witkowska, Matuszewska i Kompa, 2008, s. 164-165). Następnie średnie ruchome zaczęto używać jako ruchome poziomy wsparcia i oporu dla ceny, które pierwotnie były stosowane do wyznaczenia zasięgu fal wzrostowych lub spadkowych (Murphy, 1995, s. 247; Nisson, 1996, s. 147-148; Pring, 1998, s. 97-99). Kolejnym zastosowaniem średnich ruchomych była budowa kopert cenowych, powstających w wyniku dodania lub odjęcia od średniej ruchomej jej określonej części (np. 10\%). Tego typu przesunięcie zwane jest translacją wertykalną średniej. Dalsze modyfikacje doprowadziły do przesunięcia średniej ruchomej o kilka sesji w przód lub w tył, a wygenerowane w ten sposób wskazania były wykorzystywane do zawierania transakcji kupna lub sprzedaży. Taki zabieg nosi nazwę translacji horyzontalnej. Skalrew (1980) zaproponował przesunięcie średnich w przód lub w tył o liczbę dni równą pierwiastkowi kwadratowemu długości tej średniej, przy zaokrągleniu otrzymanego rezultatu w górę, do liczby całkowitej. Średnie o długościach od 2 do 4 sesji przesuwane są więc o 2 dni, o długościach od 5 do 9 sesji - o 3 sesje, o długościach od 10 do 16 sesji-o 4 sesje itd.

$\mathrm{Na}$ bazie średnich ruchomych kalkulowane są też takie narzędzia analizy technicznej, jak: wstęgi Bollingera, wstęgi Starc i kanały Keltnera (Nowakowski i Borowski, 2005, s. 33-35). Jeszcze inną metodę wykorzystania średnich ruchomych zaproponowali Japończycy. Według nich wskazania kupna powstają wtedy, gdy średnia ruchoma $\mathrm{N}_{1}$-sesyjna przełamuje od dołu średnią ruchomą $\mathrm{N}_{2}$-sesyjną (przy czym zachodzi warunek, że $\mathrm{N}_{1}<\mathrm{N}_{2}$ ). Sygnał sprzedaży ma miejsce, gdy średnia $\mathrm{N}_{1}$ przełamuje od góry średnią $\mathrm{N}_{2}$. Wskazania te noszą odpowiednio nazwy: złoty krzyż i krzyż śmierci (Witkowska i in., 2008, s. 164-165). Powyższe rozważania pozwalają na wyznaczenie następujących stopni swobody średniej ruchomej:

1. Cena, z jakiej obliczana jest średnia ruchoma (w większości przypadków jest to cena zamknięcia dla obserwowanego interwału czasowego).

2. Sposób kalkulacji średniej (prosta, ważona liniowo, ważona wykładniczo itd. - zagadnienie to zostanie poruszone w dalszej części artykułu).

3. Długość uśredniania średniej, tj. z jakiego interwału czasowego zostanie wyliczona wartość średniej ruchomej (np. z 10 czy 15 sesji).

4. Wielkość przesunięcia wertykalnego o X\% wartości średniej (w górę lub w dół).

5. Wielkość przesunięcia horyzontalnego o $N$ interwałów czasowych (przykładowo o 5 sesji), w przód lub wstecz.

W toku dalszych prac nad średnimi ruchomymi wprowadzono również systemy transakcyjne oparte o przecięcie trzech średnich ruchomych (np. 4-, 9- i 18-se- 
syjnych na rynku akcji czy 5-, 10- i 20-sesyjnych na rynku surowców) (Murphy, 1995, s. 248-250). Wdrożono też tzw. podwójne i potrójne wygładzanie średnich ruchomych, kiedy druga średnia jest kalkulowana na bazie pierwszej, a trzecia z wykorzystaniem drugiej (Kaufman, 1978, s. 66-67).

Jednym z podstawowych parametrów stosowanych w procesie kalkulacji średnich ruchomych jest sposób uśredniania. Do najbardziej popularnych średnich ruchomych można zaliczyć:

- średnią zwykłą (Simple Moving Average - SMA),

- średnią ważoną liniowo (Weighted Moving Average - WMA),

- średnią ważoną wykładniczo (Exponent Moving Average - EMA).

Zwykła średnia ruchoma $N$-sesyjna wyrażona jest za pomocą wzoru (Kaufman, 1978, s. 58-59):

$$
S M A_{t}=\frac{C_{1}+C_{2}+\cdots+C_{N}}{N}
$$

gdzie: $C_{i}$ - cena w i-tym interwale czasowym.

$\mathrm{Z}$ kolei średnia ruchoma ważona liniowo opisana jest za pomocą wzoru (Kaufman, 1978, s. 64-66):

$$
W M A_{t}=\frac{C_{1} \cdot 1+C_{2} \cdot 2+\cdots+C_{N} \cdot N}{1+2+\cdots+N} .
$$

Wykładnicza średnia ruchoma może być przedstawiona jako (Kaufman, 1978, s. 60):

$$
E M A_{t}=\frac{C_{1} \cdot a^{N-1}+C_{2} \cdot a^{N-2}+\cdots+C_{N} \cdot a^{0}}{a^{N-1}+a^{N-2}+\cdots+a^{0}}
$$

przy warunku, że parametr $a \in(0,1]$.

Każda z tych średnich ma wady i zalety. W przypadku średniej SMA wszystkie ceny w badanym interwale czasowym mają taką samą wagę. W przypadku średniej ruchomej 15-sesyjnej cena sprzed 3 tygodni jest więc tak samo ważna, jak ostatnia cena. Fakt ten stoi w sprzeczności z podejściem wyrażanym przez inwestorów, dla których ostatnia cena jest zdecydowanie bardziej istotna niż pierwsza w danym horyzoncie czasu. Dlatego ich zdaniem średnie ruchome WMA oraz EMA reprezentują podejście zgodne z oczekiwaniami inwestorów. W przypadku średniej WMA waga cen $\mathrm{w}$ oknie uśredniania maleje liniowo, co nie jest zgodne $\mathrm{z}$ teorią finansów behawioralnych, według której wykładnicza zmiana wag w średniej ruchomej jest bliższa mentalnemu sposobowi ważenia cen przez inwestorów. Twierdzi się, że średnia EMA najlepiej spośród trzech średnich (SMA, EMA i WMA) oddaje sposób ważenia cen przez inwestorów w swoich umysłach (Aronson, 2007, s. 25-27). System transakcyjny, oparty o przecięcie ceny i średniej ruchomej, generuje dużą liczbę wskazań w przypadku, gdy cena znajduje się w trendzie bocznym. Z kolei w wyraźnych trendach wertykalnych wskazania takiego systemu stają się bardziej trafne, przy czym obowiązuje tutaj prawidłowość, że im mniejsza długość średniej, 
tym więcej błędnych sygnałów zajęcia pozycji długiej lub jej likwidacji. Z kolei wydłużenie okresu uśredniania prowadzi do powstawania mniejszej liczby sygnałów kupna lub sprzedaży, bardziej wiarygodnych, ale i bardziej opóźnionych w stosunku do ekstremów cenowych (opóźnienie wertykalne i horyzontalne).

Oprócz wyżej wymienionych średnich (SMA, WMA, EMA) na rynkach finansowych stosuje się także inne średnie, takie jak: średnia ruchoma ważona wolumenem obrotów, średnia ruchoma z uwzględnieniem free float, sinusoidalnie ważona średnia ruchoma, trójkątnie ważona średnia ruchoma, średnia ruchoma jednego dnia tygodnia czy fraktalna, adaptacyjna średnia ruchoma (FRAMA) (Kaufman, 2013, s. 289-293; Mastalerz-Kodzis, 2013).

Średnie ruchome są wykorzystywane do budowy systemów transakcyjnych opartych na przecięciu średniej ruchomej i ceny instrumentu finansowego. W literaturze przedmiotu stosunkowo dużo miejsca poświęca się problematyce tego typu systemów transakcyjnych, w tym głównie problemowi ich optymalizacji (Grebenkov i Serror, 2014). Mało zbadanym zagadnieniem jest kwestia tego, czy w przypadku systemów transakcyjnych opartych o średnie ruchome należy posługiwać się średnią ruchomą zwykłą, ważoną liniowo czy może ważoną wykładniczo. Dlatego celem niniejszego artykułu jest określenie efektywności i stabilności systemów transakcyjnych wykorzystujących średnie ruchome EMA, SMA i WMA dla spółek notowanych na Giełdzie Papierów Wartościowych (GPW) w Warszawie.

Hipoteza badawcza została sformułowana w sposób następujący: Dla większości spółek notowanych na GPW w Warszawie system transakcyjny oparty o wskazania kupna i sprzedaży, tworzone przez przecięcia średniej ruchomej i ceny zamknięcia walorów, przynosił najwyższe stopy zwrotu dla średnich WMA, w mniejszym odsetku zaś odpowiednio dla średnich SMA i EMA.

Podejście zaprezentowane $\mathrm{w}$ tym artykule ma charakter odmienny od dotychczasowych, ponieważ nie chodzi o wskazanie długości średniej ruchomej optymalizującej system transakcyjny dla pojedynczego instrumentu finansowego (lub kilku dowolnie wybranych), lecz o spojrzenie globalne na całą grupę takich średnich dla wszystkich spółek notowanych na GPW w Warszawie. Autorowi nie są znane inne badania tak szeroko obejmujące spółki z GPW w Warszawie.

\section{Przegląd literatury}

Pring (1998, s. 100) ustanowił podział średnich ze względu na horyzont inwestycyjny. I tak średnie o długościach 10, 15, 20, 25 i 30 sesji uznał za krótkoterminowe, o długościach 50, 65, 100 i 200 sesji - za średnioterminowe, a średnie 45-tygodniowe oraz 12-, 18- i 25-miesięczne - za długoterminowe. Inną klasyfikację zaproponował Gatley (1999, s. 37). Według niego średnie krótkoterminowe to 20-sesyjne, średnioterminowe - 50-sesyjne, a długoterminowe - 200-sesyjne. Zdaniem Achelisa (1998, s. 26) średnia 200 -sesyjna zalicza się już do średnich długoterminowych. W wielu 
przypadkach stosuje się również liczby wchodzące w skład ciągu Fibonacciego (np. 13, 21, 34, 55, 89 itd.) lub ich kombinacje, jak np. 13- i 55-sesyjne (Letkowski, 2014), łączące je w sposób umowny z długością horyzontu inwestycyjnego. W związku z powyższym można zauważyć, że nie istnieje jednolity podział na średnie krótko-, średnio-i długoterminowe, który by był powszechnie przyjęty na rynkach finansowych bądź w literaturze poświęconej analizie technicznej. Na polskim rynku akcji przyjęło się stosowanie średnich ruchomych o długościach 10, 15 i 45 sesji (Tarczyński i Łuniewska, 2004, s. 17-18).

Za istotne uznaje się prace poświęcone testowaniu systemów transakcyjnych opartych o średnie ruchome autorstwa Brocka, Lakonishoka i LeBarona (1992) oraz Faber (2007). W pierwszej z nich zaprezentowano 26 reguł podejmowania decyzji z wykorzystaniem pojedynczych lub kilku średnich ruchomych na bazie danych dla indeksu DJIA z lat 1897-1986. Pozycja ta zapoczątkowała rozwój badań nad wykorzystaniem średnich ruchomych na rynkach finansowych z uwzględnieniem kosztów transakcyjnych oraz $\mathrm{w}$ różnych interwałach czasowych. Z kolei Faber porównała stopy zwrotu uzyskane za pomocą aktywnych strategii inwestycyjnych, bazujących na średnich ruchomych (głównie były to systemy stosujące jedną średnią ruchomą), ze stopami zwrotu otrzymanymi w strategii kup i trzymaj (strategia pasywna). Autorka m.in. udowodniła, że strategia oparta na sygnałach kupna i sprzedaży 10-miesięcznej średniej ruchomej dla indeksu S\&P 500 przynosiła w ciągu 100 lat objętych badaniem stopę zwrotu wyższą przy jednocześnie niższej zmienności niż strategia kup i trzymaj. Metodologia Faber została rozciągnięta na rynki międzynarodowe w badaniach przeprowadzonych przez Gwilyma, Clare'a, Seatona i Thomasa (2010), Kilgallena (2012) oraz Moskowitza, Ooi i Pedersena (2012).

Fifield, Power i Knipe (2008), analizując strategie inwestycyjne oparte na średnich ruchomych dla 5 rynków rozwiniętych i 15 emerging markets w okresie 1989-2003, doszli do wniosku, że na tych rynkach są one bardziej efektywne. Co ciekawe, również zastosowanie dłuższych średnich ruchomych na rynkach emerging markets prowadziło do uzyskania wyższych stóp zwrotu. Bolton i von Boetticher (2015) dowiedli, że w okresie od 1 marca 2009 r. do 8 kwietnia 2014 r. zastosowanie średniej ruchomej EMA dało wyższe stopy zwrotu z inwestycji w portfel replikujący indeks giełdy w Johannesburgu ALSI TOP 40 (strategia pasywna) niż średniej ruchomej SMA. System transakcyjny oparty o średnie ruchome SMA i EMA dla indeksów giełdy w Indiach (Nifty i Junior Nifty) w okresie od grudnia 2000 r. do listopada 2010 r. był przedmiotem badań Mitry (2011), który wykazał, że jedynie w nielicznych przypadkach system transakcyjny bazujący na przecięciu przez cenę średniej ruchomej przynosił wyższe stopy zwrotu niż strategia kup i trzymaj. Hochheimer (1978) udowodnił, że wyniki uzyskiwane przez system transakcyjny na bazie zwykłej średniej ruchomej (SMA) były wyższe niż w przypadku zastosowania średniej ruchomej ważonej wykładniczo (EMA). Z kolei zdaniem Appela (2005) lepsze wyniki przynoszą systemy transakcyjne wykorzystujące wykładniczą średnią ruchomą (EMA) w stosunku do opartych na zwykłej średniej ruchomej (SMA). 
Prace dotyczące zastosowania średnich ruchomych w analizie technicznej były prowadzone również na polskim rynku kapitałowym. Filar i Kąkol (2013) stworzyli system transakcyjny dla średnich ruchomych o dwóch długościach - 12- i 100-sesyjnej - dla indeksu giełdowego WIG20 i spółek: Bogdanka, KGHM, PGE, PKO BP, Lotos, TVN, dla kwotowań z okresu od 1 stycznia 2012 r. do 31 grudnia 2012 r. W badaniach posłużyli się trzema rodzajami średnich ruchomych: zwykłą, ważoną wykładniczo i liniowo. Otrzymane przez autorów rezultaty wykazały wyższą skuteczność średnich krótkoterminowych niż średnich długoterminowych. W przypadku tych ostatnich za niską stopę zwrotu odpowiedzialne były duże wahania sygnałów kupna i sprzedaży w stosunku do lokalnych ekstremów ceny, co prowadziło do znacznych spadków wartości portfela. Juszczuk i Kozak (2016) skupili się na rynku walutowym, na którym poddano analizie wpływ zwiększenia długości średniej na uzyskiwane wyniki, Salamaga (2013) zaś uwzględnił wpływ kosztów transakcyjnych i inwestorów instytucjonalnych na osiągane stopy zwrotu. Z kolei praca Czuby i Kaszuby (2009) została poświęcona głównie analizie różnic w występowaniu sygnałów kupna i sprzedaży pomiędzy różnymi rodzajami średnich (zwykła, ważona wykładniczo i liniowo).

Górska (2011) stworzyła system transakcyjny, w skład którego weszły średnie ruchome (zwykła, ważona wykładniczo i liniowo) 5- i 10-sesyjna oraz oscylatory analizy technicznej: MACD (o długościach: 8, 17, 9 i 12, 26, 9 sesji), Momentum (o długościach 5, 9 oraz 10, 9 sesji) i Commodity Channel Index (o długościach 5 i 10 sesji). Na podstawie przeprowadzonych badań autorka wyciągnęła wniosek, że systemy transakcyjne wykorzystujące wskaźniki i oscylatory analizy technicznej okazały się bardziej skuteczne na rynku wybranych surowców od tych bazujących na średnich ruchomych. W badaniu dotyczącym wykorzystania systemu transakcyjnego opartego na średnich ruchomych (prostej 10-sesyjnej, prostej 10-sesyjnej z filtrem 2,5\% lub filtrem 3-dniowym, dwóch średnich ruchomych 5- i 20-sesyjnej, ważonej liniowo średniej 10-sesyjnej, wykładniczej średniej ruchomej 10-sesyjnej), oscylatora MACD (o długościach średnich 12, 26 i 9 sesji) oraz oscylatorów Momentum (10-sesyjnego) i CCI (5-sesyjnego), testowanym dla wybranych spółek i indeksów z GPW w Warszawie oraz niektórych surowców na bazie cen z okresu od 2 marca 2009 r. do 29 lipca 2011 r., najbardziej skuteczną dla walorów Synthos i indeksu WIG-Chemia okazała się średnia ruchoma EMA. Z kolei najwyższy zysk przyniosła SMA w przypadku indeksu WIG-Spożywczy (Górska, 2008). Letkowski (2014) dokonał analizy skuteczności systemu transakcyjnego wykorzystującego zwykłą średnią ruchomą o długościach 10, 20, 30, 40, 50, 60, 70, 80, 90 i 100 sesji dla wybranych spółek wchodzących w skład indeksu WIG20 oraz dla samego indeksu WIG20 w okresie 2003-2012. Na podstawie otrzymanych rezultatów stwierdził, że w przypadku pewnej grupy spółek (BRE Bank, Bank Handlowy, PKN Orlen, KGHM, Bank PEKAO) najlepsze wyniki generował system posługujący się średnią ruchomą 10-sesyjną, natomiast dla innej grupy spółek (Telekomunikacja Polska, Boryszew, Asseco) optymalną okazała się średnia o długości 100 sesji. 
Problematyka efektywności systemów transakcyjnych i ich oceny została poruszona m.in. w pracach Katsanosa (2009, s. 149-165), Kaufmana (2013, s. 58-59), LeBeau i Lucasa (2016) oraz Zalewskiego (2001).

\section{Metodologia badania}

W badaniu wzięto pod uwagę 404 spółki notowane na GPW w Warszawie, których debiut na giełdzie miał miejsce przed 1 stycznia 2018 r. Dla każdej z nich obliczono 16 długości średnich ruchomych, które przyniosły najwyższe stopy zwrotu w system transakcyjny oparty o przecięcie średniej ruchomej i ceny zamknięcia. Obliczeń dokonano w programie Metastock XV. W dalszej części artykułu przyjęto następującą konwencję oznaczeń w postaci KMAX, gdzie KMA oznacza określony rodzaj średniej ruchomej (tj. SMA, WMA lub EMA), a X - pozycję średniej KMA pod względem stóp zwrotu w grupie średnich typu KMA. I tak np. SMA I oznacza średnią ruchomą zwykłą, która przyniosła najwyższą stopę zwrotu w analizowanym okresie dla danego instrumentu, a EMA XVI to średnia ruchoma ważona wykładniczo, która przyniosła szesnastą w kolejności stopę zwrotu (w dalszej części opracowania będzie ona nazywana szesnastą najwyższą stopą zwrotu).

W procesie testowania systemów transakcyjnych przyjęto następujące założenia:

1. Liczba sesji, dla których optymalizowano system - 5000 sesji, liczonych wstecz od dnia 31 marca 2019 r. ${ }^{1}$ Jeśli akcje spółki nie były notowane w tak długim interwale czasowym, wtedy system był optymalizowany w okresie: data debiutu spółki - 31 marca $2019 \mathrm{r}$.

2. Wszystkie transakcje zawierane są po cenach zamknięcia $(\mathrm{C}-$ close $)$ na sesji, na której następuje wygenerowanie sygnału kupna lub sprzedaży. Takie podejście można uznać za realne, biorąc pod uwagę fakt, że po ustaleniu ceny zamknięcia na fixingu popołudniowym ( $\mathrm{tj}$. między godz. 16:50 a 17:00) przez 10 minut istnieje możliwość przeprowadzenia transakcji właśnie po cenie zamknięcia.

3. Dla każdego waloru optymalizowano system, bazując na SMA, WMA i EMA.

4. Długości analizowanych średnich zmieniały się od 3 do 250 sesji, z krokiem co 1 sesja.

5. Nie uwzględniono kosztów transakcyjnych.

6. Ceny walorów zostały zaczerpnięte ze strony internetowej bossa.pl i skorygowane o wypłacone dywidendy na podstawie informacji z serwisu Notoria.pl.

Analiza długości średnich i stóp zwrotu została przeprowadzona z podziałem na przynależność spółek do indeksów giełdowych i branż.

1 Wybranie długiego horyzontu inwestycyjnego złożonego z 5000 sesji ma się przyczynić do wyeliminowania przypadkowości w uzyskiwanych wynikach badań. 
W procesie ewaluacji efektywności systemów transakcyjnych jednym z czynników jest ocena jego stabilności. Podobna ocena została przeprowadzona również w analizowanym przypadku. Dla każdego waloru i każdej średniej ruchomej (SMA, WMA, EMA) uzyskano po 16 długości średnich ruchomych, przynoszących w kolejności 16 najwyższych stóp zwrotu. Na tej podstawie obliczono średni spadek efektywności systemu dla 16 najlepszych transakcji, którego wartość wyrażana jest w punktach procentowych:

$$
W S=\frac{1}{15} \cdot \sum_{n=1}^{n=15} W_{n+1}-W_{n}
$$

gdzie:

WS - średni spadek efektywności dla 16 najlepszych systemów transakcyjnych, dla danego waloru i danego rodzaju średniej,

$W_{n}-n$-ta najlepsza stopa zwrotu dla danego waloru spośród 16 długości średnich ruchomych, które przyniosły najwyższe stopy zwrotu w analizowanym okresie, przy czym $W_{1}$ oznacza najwyższą stopę zwrotu (KMA I), a $W_{16}$ - najniższą stopę zwrotu (KMA XVI).

W celu przeprowadzenia porównań między spółkami konieczne było odniesienie wartości $W S$ do $W_{1}$ :

$$
W F=\frac{W S}{W_{1}} .
$$

Interpretacja ekonomiczna parametru WF pozwala na stwierdzenie, że jest to średni spadek efektywności 16 najlepszych systemów transakcyjnych przypadający na jednostkową stopę zwrotu najlepszego systemu transakcyjnego. System transakcyjny można uznać za stabilny dla małych wartości WF (wynoszących kilka procent). Jeśli system transakcyjny cechuje się niestabilnością, wtedy mamy do czynienia z dużą różnicą stóp zwrotu między najlepszym a szesnastym w rankingu wynikiem, co przekłada się także na dużą wartość parametru WF.

Część aplikacyjna artykułu została podzielona na trzy bloki, w których zastosowano następujące metody badawcze:

1. Średnie ruchome optymalizujące system transakcyjny - analiza korelacji stóp zwrotu i długości średnich ruchomych optymalizujących system transakcyjny, regresja liniowa.

2. Ranking skuteczności systemów transakcyjnych - rankingowanie proste i ważone stopą zwrotu.

3. Analiza stabilności systemów transakcyjnych - korelacja długości pierwszej i drugiej średniej ruchomej (przynoszących najwyższe stopy zwrotu), współczynnik determinacji dla par średnich ruchomych i stóp zwrotu, a także współczynnik WF. 


\section{Dyskusja wyników}

\section{Ocena efektywności systemów transakcyjnych opartych o różne rodzaje średnich ruchomych}

W przypadku wszystkich rodzajów średnich (SMA, EMA, WMA) średnie ruchome, które optymalizowały system transakcyjny, były głównie średnimi krótkoterminowymi (rysunek 1). W grupie średnich krótszych niż 53-sesyjne odsetek średnich ruchomych SMA w przedziałach 3-7, 8-12, 13-17, 23-27 i 43-47 był wyższy niż średnich EMA. Dla dłuższych średnich ruchomych (tj. dłuższych niż 53 sesje) tendencja ta ulegała odwróceniu. W obszarze średnich długoterminowych widoczna była dominacja średnich WMA (w przedziałach 183-187 i 193-197).

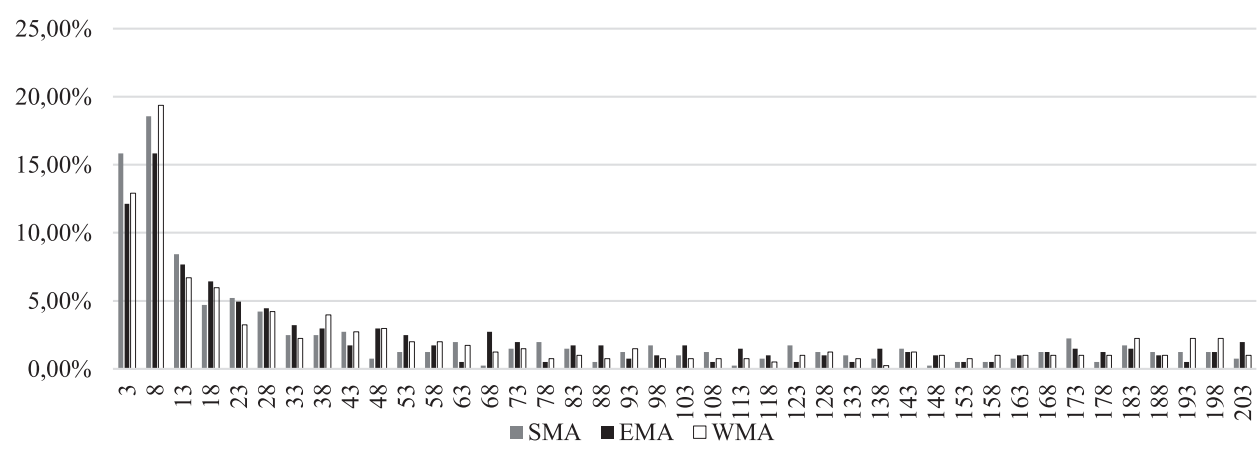

Rysunek 1. Odsetek średnich ruchomych SMA, EMA i WMA, które optymalizowały system transakcyjny, jako funkcja ich długości

Uwaga: na dole pokazano początkową wartość przedziału i skok przedziału 5 jednostek; liczba 3 oznacza przedział 3-7, a liczba 13 - przedział 13-17

Źródło: opracowanie własne.

Porównanie stóp zwrotu dla poszczególnych rodzajów średnich ruchomych, optymalizujących system transakcyjny dla analizowanych papierów wartościowych, prowadzi do wniosku, że dla danego papieru wartościowego system transakcyjny, oparty na średniej WMA, przynosił najczęściej najwyższą stopę zwrotu w stosunku do systemu wykorzystującego inne ważenia cen (SMA czy EMA) (tabela 1). W 54,32\% przypadków maksymalna stopa zwrotu dla WMA I była wyższa od maksymalnej stopy zwrotu dla SMA I. Różnice między najlepszym systemem WMA I i EMA I były jeszcze większe, ponieważ aż w 70,86\% maksymalna stopa zwrotu dla WMA I była wyższa od maksymalnej stopy zwrotu dla EMA I. Z kolei na podstawie konfrontacji stóp zwrotu dla SMA I i EMA I można stwierdzić, że w 74,81\% system bazujący na średniej ruchomej zwykłej przynosił wyższą stopę zwrotu niż system posługujący się średnią ważoną wykładniczo. Analiza powyższych wyników pozwala na stworzenie rankingu średnich ruchomych, w którym na pierwszym miejscu pod względem czę- 
stości uzyskiwania najwyższych stóp zwrotu znalazła się średnia ruchoma WMA, nieznacznie wyprzedzając średnią SMA. Na trzecim miejscu uplasowała się średnia EMA, która mniej niż w $26 \%$ analizowanych przypadków generowała najwyższą stopę zwrotu w stosunku do stóp zwrotu uzyskiwanych za pomocą systemów bazujących na SMA czy WMA.

Tabela 1. Odsetek przypadków, w których stopa zwrotu z jednej średniej była wyższa od stopy zwrotu z drugiej średniej

\begin{tabular}{|c|c|}
\hline Warunek & Odsetek przypadków \\
\hline SMA > EMA & $74,81 \%$ \\
\hline WMA > SMA & $54,32 \%$ \\
\hline WMA > EMA & $70,86 \%$ \\
\hline
\end{tabular}

Źródło: opracowanie własne.

Maksymalna stopa zwrotu uzyskana dla średniej SMA była wyższa od maksymalnej stopy zwrotu otrzymanej z użyciem średniej EMA w: 90\% dla spółek z indeksu WIG20, 65\% - dla spółek z indeksu mWIG40, 85,19\% - dla spółek z indeksu sWIG80, 71,48\% - dla pozostałych spółek (tj. niewchodzących w skład żadnego z tych indeksów). W przypadku spółek z indeksu WIG20 wskazane jest zatem posługiwanie się średnią ruchomą zwykłą, podobnie jak w przypadku spółek z indeksu sWIG80. Odnośnie do spółek z indeksu mWIG40 lepsze wyniki optymalizacji systemu transakcyjnego nadal były uzyskiwane dla średnich SMA, przy czym odsetek średnich EMA generujących optymalne wartości dla badanej strategii inwestycyjnej był już znacznie większy niż dla spółek z indeksów WIG20 czy sWIG80.

Dla średnich SMA I i WMA I najwyższy odsetek przypadków, w których maksymalna stopa zwrotu z użyciem pierwszej średniej była wyższa niż maksymalna stopa zwrotu z wykorzystaniem drugiej średniej, odnotowano dla spółek z indeksu WIG20 (50\%) przed spółkami niewchodzącymi w skład żadnego z indeksów (48,29\%) oraz spółkami z indeksów sWIG80 (43,21\%) i mWIG40 (30,00\%). W przypadku średnich EMA I i WMA I stopy zwrotu uzyskane z wykorzystaniem tej drugiej średniej były wyższe dla wszystkich indeksów niż przy zastosowaniu średniej pierwszej: WIG20 -75\%, mWIG40 - 60\%, sWIG80 - 77,78\%, pozostałe spółki - 69,96\%. Otrzymane wyniki potwierdzają wcześniej sporządzony ranking średnich ruchomych - WMA przed SMA i EMA, jak również pozwalają zauważyć fakt, że różnice stóp zwrotu między systemami opartymi o WMA i SMA nie są tak duże, jak między stopami zwrotu w systemach, w których jedną średnią jest WMA lub SMA, a drugą - EMA.

Dominacja WMA nad SMA i EMA pod względem najwyższego odsetka maksymalnych stóp zwrotu jest też widoczna w przypadku podziału spółek na siedem sektorów branżowych (podział według portalu Notoria Service) (rysunek 2). W przypadku średnich WMA i SMA jedynie dla sektorów Chemia i Dobra konsumpcyjne odsetek najwyższych stóp zwrotu uzyskanych za pomocą średniej SMA był zbliżony do odsetka najwyższych stóp zwrotu osiągniętych z wykorzystaniem średniej WMA. 
Z kolei zestawienie wyników dla par SMA i EMA oraz WMA i EMA prowadzi do jednoznacznych wniosków - dla wszystkich sektorów odsetek najwyższych stóp zwrotu był wyższy dla średniej SMA niż EMA oraz średniej WMA niż EMA.

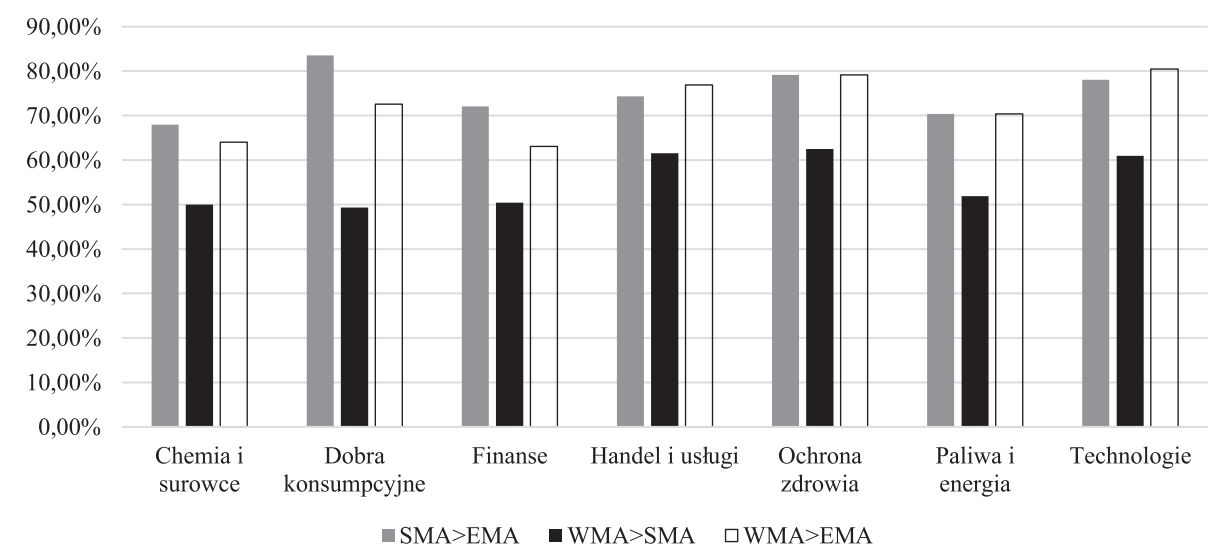

Rysunek 2. Odsetek przypadków, w których stopa zwrotu z systemu transakcyjnego używającego jednego rodzaju średniej była wyższa od stopy zwrotu dla systemu wykorzystującego drugą średnią

Źródło: opracowanie własne.

Współczynnik korelacji długości średnich SMA i EMA optymalizujących system transakcyjny wyniósł 0,6201, a dla średnich SMA i WMA-0,6903. Najniższą wartość współczynnika korelacji odnotowano dla długości średnich EMA i WMA $(0,6112)$ (tabela 2). Wartość współczynnika korelacji średnich ruchomych SMA i EMA, które dały drugie najwyższe wyniki optymalizacji systemu, jest równa 0,6842 . Dla pozostałych par średnich, generujących najwyższe stopy zwrotu, wartości współczynnika korelacji wyniosły 0,6205 (SMA i WMA) oraz 0,5554 (EMA i WMA). Zależności między długościami średnich ruchomych SMA I i EMA I jako przykładowe zostały pokazane na rysunku 3, a między SMA II i EMA II - na rysunku 4.

Tabela 2. Wartości współczynników korelacji długości najlepszych i drugich najlepszych średnich ruchomych

\begin{tabular}{|l|c|c|c|c|c|c|}
\hline & \multicolumn{3}{|c|}{ I średnia } & \multicolumn{3}{c|}{ II średnia } \\
\cline { 2 - 7 } & SMA & EMA & WMA & SMA & EMA & WMA \\
\hline SMA & 1 & 0,6201 & 0,6903 & 1 & 0,6842 & 0,6205 \\
\hline EMA & - & 1 & 0,6112 & - & 1 & 0,5554 \\
\hline WMA & - & - & 1 & - & - & 1 \\
\hline
\end{tabular}

Źródło: opracowanie własne.

Z kolei wartość współczynnika korelacji najwyższych stóp zwrotu uzyskanych przez system transakcyjny dla średnich SMA i EMA okazała się bardzo wysoka $(0,9972)$ i była niewiele większa niż dla współczynnika korelacji stóp zwrotu systemów transakcyjnych opartych na SMA i WMA $(0,9966)$ czy EMA i WMA $(0,9968)$. 


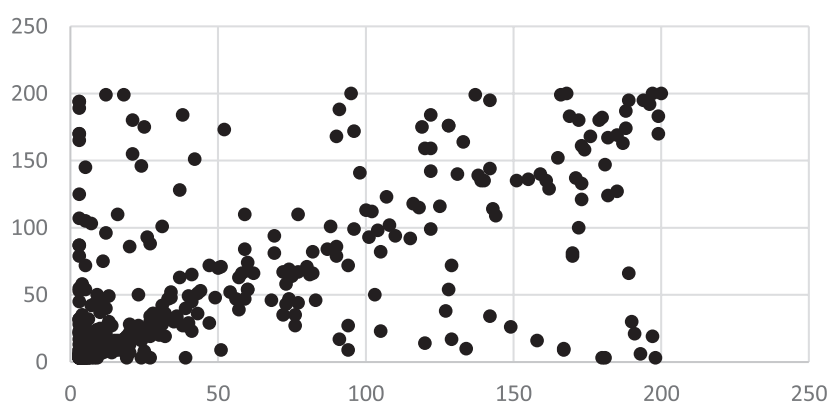

Rysunek 3. Zależności między długościami średnich ruchomych SMA I (oś odciętych) i EMA I (oś rzędnych) dla wszystkich analizowanych spółek

Źródło: opracowanie własne.

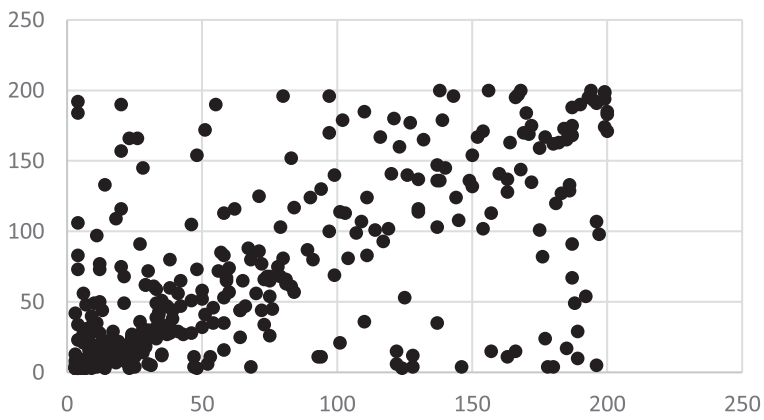

Rysunek 4. Zależności między długościami średnich ruchomych SMA II (oś odciętych) i EMA II (oś rzędnych) dla wszystkich analizowanych spółek

Źródło: opracowanie własne.

Ten sam współczynnik korelacji obliczony dla 16 stóp zwrotu w rankingu systemów transakcyjnych dla średnich SMA i EMA wyniósł 0,9943 i ponownie był najwyższy spośród współczynników korelacji stóp zwrotu dla systemów z wykorzystaniem SMA i WMA $(0,9831)$ oraz EMA i WMA $(0,9808)$. Na rysunkach 5 i 6 zamieszczono przykłady zależności między stopami zwrotu dla EMA I i SMA I oraz EMA XVI i SMA XVI dla wszystkich analizowanych walorów.

Tabela 3. Wartości współczynników korelacji stóp zwrotu dla najlepszych i 16 najlepszych systemów transakcyjnych

\begin{tabular}{|l|c|c|c|c|c|c|}
\hline & \multicolumn{3}{|c|}{ I Wyniki } & \multicolumn{3}{c|}{ 16 Wyniki } \\
\cline { 2 - 7 } & SMA & EMA & WMA & SMA & EMA & WMA \\
\hline SMA & 1 & 0,9972 & 0,9966 & 1,0000 & 0,9943 & 0,9831 \\
\hline EMA & - & 1 & 0,9968 & - & 1 & 0,9808 \\
\hline WMA & - & - & 1 & - & - & 1 \\
\hline
\end{tabular}


Pobrane z czasopisma Annales H - Oeconomia http://oeconomia.annales.umcs.pl

Data: 26/04/2023 15:44:13

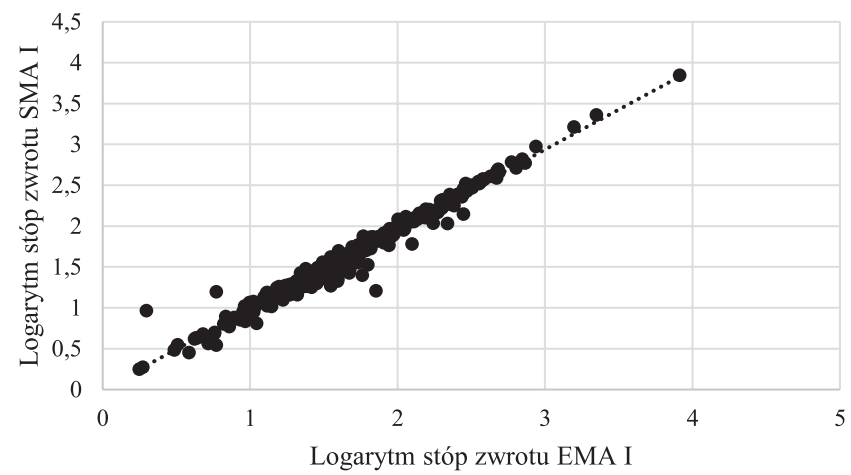

Rysunek 5. Zależność między stopami zwrotu dla najlepszych systemów transakcyjnych (EMA I i SMA I) Źródło: opracowanie własne.

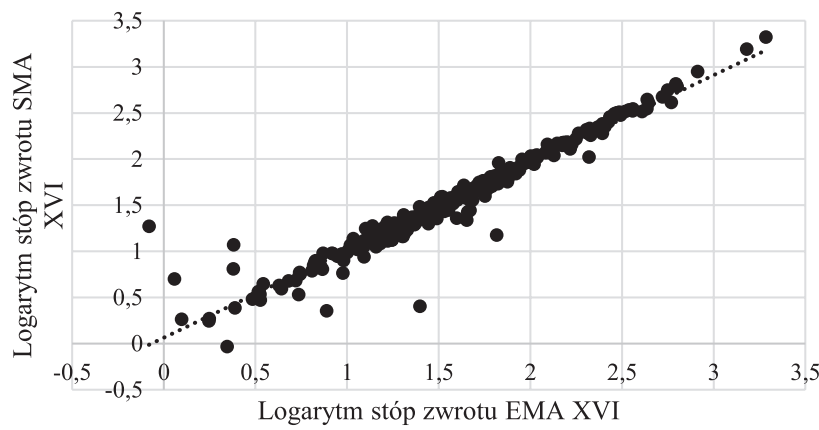

Rysunek 6. Zależność między stopami zwrotu dla 16 najlepszych systemów transakcyjnych (EMA XVI i SMA XVI)

Źródło: opracowanie własne.

\section{Ranking skuteczności systemów transakcyjnych wykorzystujących średnie ruchome}

Ranking skuteczności systemów transakcyjnych został sporządzony na dwa sposoby. Po pierwsze, w wyniku przeprowadzonych obliczeń dla każdego papieru wartościowego uzyskano trzy długości średnich SMA, EMA i WMA, które optymalizowały system transakcyjny, dając trzy stopy zwrotu: $\mathrm{r}_{\mathrm{SMA}}, \mathrm{r}_{\mathrm{EMAI}} \mathrm{i}_{\mathrm{WMA}}$ (są to zatem najwyższe stopy zwrotu dla każdego papieru wartościowego, uzyskane z wykorzystaniem średnich SMA, EMA i WMA). Najwyższej stopie zwrotu spośród stóp $r_{\text {SMA }}, r_{\text {EMAI }} i r_{\text {WMA }}$ przypisano ranking I, drugiej najwyższej - ranking II, a najniższej - ranking III. Następnie dokonano sumowania po wszystkich analizowanych papierach wartościowych. Średnia (SMA, EMAlub WMA), która uzyskała najniższą (najwyższą) sumę, została sklasyfikowana na miejscu pierwszym (trzecim).

Po drugie, $\mathrm{z}$ uwagi na fakt, iż ranking sporządzony w punkcie pierwszym nie uwzględnia różnic w stopach zwrotu dla poszczególnych średnich dla tego samego 
papieru wartościowego, konieczne było stworzenie rankingu pozbawionego takiej wady. Dla danego papieru wartościowego i średniej ruchomej SMA została przypisana waga:

$$
w_{S M A}=\frac{r_{S M A I}}{r_{S M A I}+r_{E M A I}+r_{W M A I}} .
$$

Analogicznie przypisano wagi pozostałym średnim ruchomym: $\mathrm{W}_{\mathrm{EMA}} \mathrm{i}_{\mathrm{MWA}_{\mathrm{A}}}$. $\mathrm{W}$ kolejnym kroku wagi $\mathrm{w}_{\mathrm{SMA}}, \mathrm{w}_{\mathrm{EMA}}$ i $\mathrm{w}_{\mathrm{MWA}}$ zostały zsumowane po wszystkich analizowanych papierach wartościowych, a następnie sporządzono ranking poszczególnych średnich zgodnie z zasadą, że najwyższą wartość w rankingu ma średnia o największej wartości sumy wag. Uzyskane wyniki zaprezentowano w tabelach 4 i 5.

Wnioski płynące z obu rankingów są analogiczne. Najlepszą średnią ruchomą okazała się średnia WMA, która wyprzedziła SMA i EMA. Analizując sumy punktów uzyskane za pomocą metody I i sumy wag (metoda II), można zauważyć, że różnica efektywności systemów transakcyjnych bazujących na WMA i SMA jest zdecydowanie mniejsza od różnicy efektywności systemów transakcyjnych wykorzystujących takie pary średnich, jak: (1) SMA i EMA oraz (2) WMA i EMA.

Tabela 4. Sumy uzyskane przy przeprowadzaniu rankingu za pomocą I i II metody

\begin{tabular}{|l|c|c|c|}
\hline & SMA & EMA & WMA \\
\hline Metoda I & 731 & 995 & 678 \\
\hline Metoda II & 135,93 & 126,53 & 140,54 \\
\hline
\end{tabular}

Źródło: opracowanie własne.

Tabela 5. Ranking średnich ruchomych otrzymany za pomocą metody I i II

\begin{tabular}{|l|c|c|c|}
\hline & SMA & EMA & WMA \\
\hline Metoda I & II & III & I \\
\hline Metoda II & II & III & I \\
\hline
\end{tabular}

Źródło: opracowanie własne.

\section{Analiza stabilności systemów transakcyjnych}

Istnieje wiele sposobów przeprowadzania analizy stabilności systemów transakcyjnych. Jednym z nich jest obserwacja długości średnich, które utworzyły system transakcyjny o najwyższej i drugiej najwyższej stopie zwrotu. W przypadku gdy systemy transakcyjne są stabilne, długości obu średnich powinny być zbliżone do siebie zgodnie z zasadą, że niewielka zmiana długości średniej prowadzi do nieco gorszego wyniku inwestycyjnego. Przy takim podejściu współczynnik korelacji długości obu średnich dla najlepszych i drugich najlepszych systemów transakcyjnych (dla wszystkich analizowanych walorów) powinien być wartością znaczącą (za taką wielkość można uznać 0,8 ). Gdyby jednak systemy były mało stabilne, wtedy 
Pobrane z czasopisma Annales $\mathrm{H}$ - Oeconomia http://oeconomia.annales.umcs.pl Data: 26/04/2023 15:44:13

długości średniej ruchomej w drugim najlepszym systemie transakcyjnym znacząco by się różniły od długości średniej w systemie przynoszącym najwyższą stopę zwrotu. Zależności między długościami średnich ruchomych SMA, EMA i WMA dla dwóch najlepszych systemów transakcyjnych i dla każdej ze średnich zostały pokazane na rysunkach 7-9.

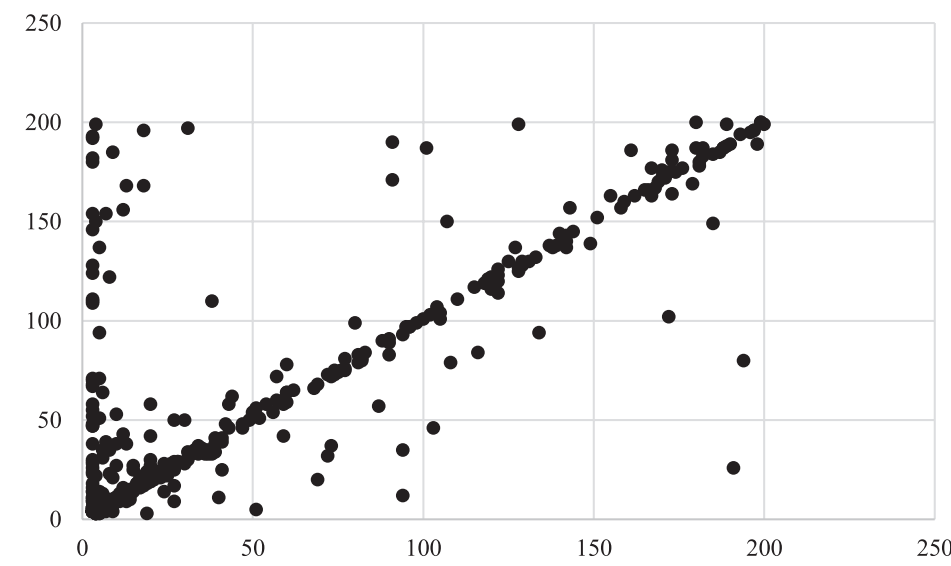

Rysunek 7. Zależności między długościami średnich ruchomych SMA dla dwóch najlepszych systemów transakcyjnych (na osi odciętych długości SMA I, a na osi rzędnych - długości SMA II)

Źródło: opracowanie własne.

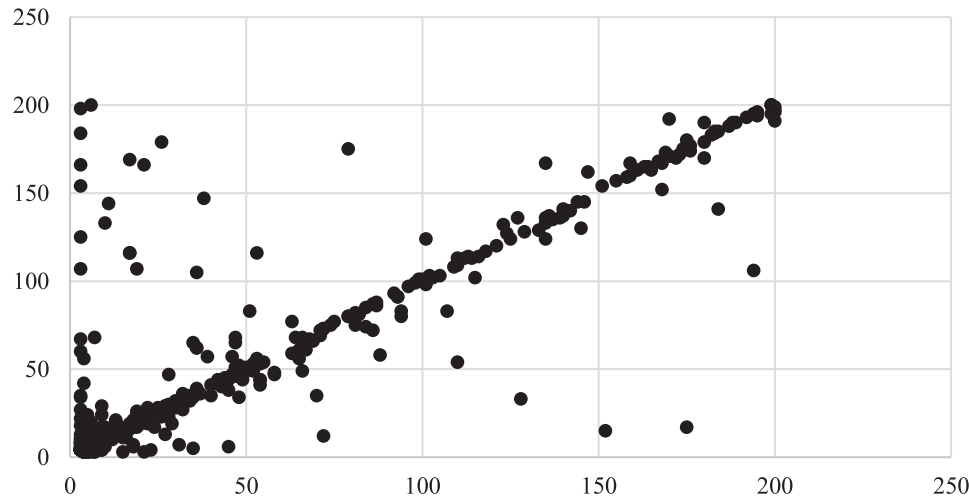

Rysunek 8. Zależności między długościami średnich ruchomych EMA dla dwóch najlepszych systemów transakcyjnych (na osi odciętych długości EMA I, a na osi rzędnych - długości EMA II)

Źródło: opracowanie własne. 


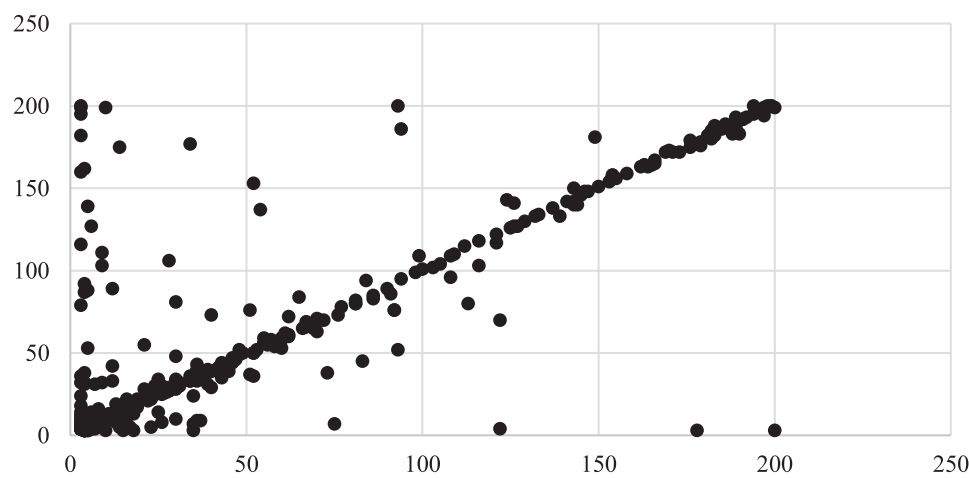

Rysunek 9. Zależności między długościami średnich ruchomych WMA dla dwóch najlepszych systemów transakcyjnych (na osi odciętych długości WMA I, a na osi rzędnych - długości WMA II)

Źródło: opracowanie własne.

Dane dotyczące współczynnika determinacji dla regresji liniowej długości średnich SMA przynoszących najwyższe stopy zwrotu (SMA I i II), średnich EMA(EMA I i II) oraz WMA (WMA I i II) zostały zamieszczone w tabeli 6. Wartość współczynnika $\mathrm{R}^{2}$ dla długości par różnych rodzajów (SMA/EMA, SMA/WMA, EMA/ WMA) średnich nie przekroczyły wartości 0,5 (tabela 6). Fakt ten upoważnia do wyciągnięcia wniosku, że dla danego papieru wartościowego, na podstawie znajomości długości średniej optymalizującej system transakcyjny, wyznaczenie długości najlepszej średniej innego rodzaju (np. wyznaczenie na podstawie SMA I wartości EMA I czy WMA I) jest obarczone dużym błędem. Z większą dokładnością można na podstawie długości średniej optymalizującej uzyskać długość drugiej najlepszej średniej ruchomej. Wartość $\mathrm{R}^{2}$ dla długości średnich EMA I i II wyniosła 0,7246 i była wyższa niż wartość tego samego współczynnika dla WMA I i II $(0,7071)$ oraz SMA I i II (0,6224), co może świadczyć o większej stabilności systemów wykorzystujących wykładniczo ważone średnie ruchome niż średnie ważone liniowo oraz zwykłe średnie.

Tabela 6. Wartość współczynnika $\mathrm{R}^{2}$ dla par średnich ruchomych

\begin{tabular}{|c|c|c|c|}
\hline Średnie & SMA I / EMA I & SMA I / WMA I & EMA I / WMA I \\
\hline $\mathrm{R}^{2}$ & 0,3844 & 0,4772 & 0,3744 \\
\hline Średnie & SMA II / EMA II & SMA II / WMA II & EMA II / WMA II \\
\hline $\mathrm{R}^{2}$ & 0,4681 & 0,3852 & 0,3086 \\
\hline Średnie & SMA I / SMA II & EMA I / EMA II & WMA I / WMA II \\
\hline $\mathrm{R}^{2}$ & 0,6224 & 0,7246 & 0,7071 \\
\hline
\end{tabular}

Źródło: opracowanie własne.

Analiza stóp zwrotu dla najlepszych systemów transakcyjnych, które przyniosły szesnastą pod względem wielkości stopę zwrotu, wykazuje wysokie wartości współczynników $\mathrm{R}^{2}$ w przypadku, gdy pierwsza i druga średnia są tego samego rzędu 
(tzn. są najlepsze albo szesnaste pod względem efektywności). Wartości wszystkich współczynników $\mathrm{R}^{2}$ były wyższe niż 0,96 , a najwyższa wartość - równa 0,9945 została odnotowana dla pary r-SMA(1) i r-EMA(1). Ostatni wiersz tabeli 7 dowodzi, że tworzenie modelu polegające na wyznaczeniu szesnastej pod względem efektywności stopy zwrotu dla tego samego typu średniej, na podstawie najwyższej stopy zwrotu, jest obarczone dużym błędem.

Tabela 7. Wartość współczynnika $\mathrm{R}^{2}$ dla stóp zwrotu średnich KMA X

\begin{tabular}{|c|c|c|c|}
\hline Wartości WF & $\mathrm{r}_{\text {SMA I }}, \mathrm{r}_{\text {EMAI }}$ & $r_{\text {SMA I }}, r_{\text {WMA I }}$ & $r_{\text {EMA I }}, r_{\text {WMA I }}$ \\
\hline $\mathrm{R}^{2}$ & 0,9945 & 0,9930 & 0,9934 \\
\hline Wartości WF & $\mathrm{r}_{\text {SMAXVI }}, \mathrm{r}_{\text {EMAXVI }}$ & $\mathrm{r}_{\text {SMAXVI }}, \mathrm{r}_{\text {WMAXVI }}$ & $\mathrm{r}_{\text {EMAXVI }}, \mathrm{r}_{\text {WMA XVI }}$ \\
\hline $\mathrm{R}^{2}$ & 0,9886 & 0,9663 & 0,9619 \\
\hline Wartości WF & $\mathrm{r}_{\text {SMAI }}, \mathrm{r}_{\text {SMAXVI }}$ & $\mathrm{r}_{\text {EMAI }}, \mathrm{r}_{\mathrm{EMAXVI}}$ & $\mathrm{r}_{\text {WMA I }}, \mathrm{r}_{\text {WMA XVI }}$ \\
\hline $\mathrm{R}^{2}$ & 0,2966 & 0,3597 & 0,4084 \\
\hline
\end{tabular}

Źródło: opracowanie własne.

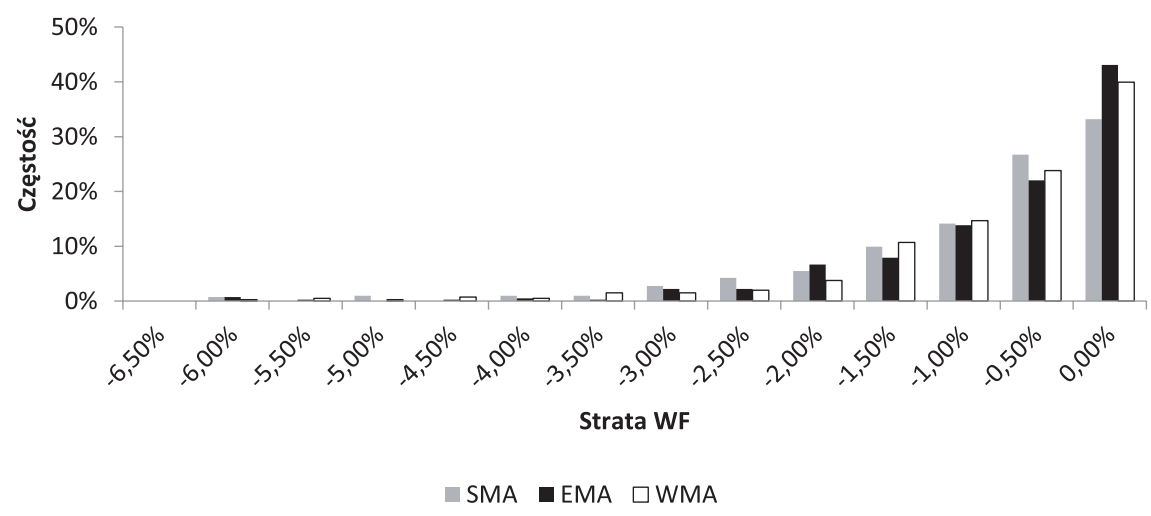

Rysunek 10. Częstość występowania strat WF dla systemów wykorzystujących średnie ruchome (wartość na dolnej osi reprezentuje dolną granicę przedziału, szerokość przedziału to 0,5 p.p.)

Źródło: opracowanie własne.

Analiza stabilności systemów transakcyjnych za pomocą miary WF również prowadzi do wniosku, że były one stosunkowo stabilne (rysunek 10), przy czym systemy bazujące na średnich WMA okazały się bardziej stabilne niż te, w których zastosowano EMA czy SMA, ponieważ w przypadku średnich wykorzystujących SMA odsetek współczynników WF większych niż -2\% wynosił $84 \%$, dla systemów opartych o EMA był on równy $87 \%$, a dla systemów używających średnich WMA uplasował się na poziomie $89 \%$. Wniosek ten jest zgodny z informacjami zamieszczonymi w tabeli 6 . 


\section{Zakończenie}

Zaprezentowane w niniejszym artykule podejście do oceny efektywności systemów transakcyjnych bazujących na średnich ruchomych można uznać za spojrzenie globalne, niejako ze statystycznego punktu widzenia. Należy jednak pamiętać, że w przypadku pojedynczej akcji trzeba stosować podejście indywidualne, a otrzymane wyniki mogą odbiegać od zaprezentowanych w opracowaniu wniosków, co można uznać za cechę indywidualną papieru wartościowego. Przeprowadzona analiza pozwala na wyciągnięcie dwóch bardzo ważnych wniosków, które można skonfrontować z rezultatami zamieszczonymi w innych publikacjach.

Po pierwsze, w przypadku wszystkich rodzajów średnich ruchomych średnimi, które optymalizowały systemy transakcyjne, były średnie krótkoterminowe. Fakt ten w pewnym stopniu potwierdza naturalną skłonność inwestorów do przeprowadzania raczej transakcji spekulacyjnych niż długoterminowych (bliższych strategii kup i trzymaj). Otrzymany wynik jest zgodny z rezultatami przedstawionymi przez Letkowskiego (2014), a także przez Filara i Kąkola (2013). Zdaniem tego pierwszego w przypadku określonej grupy spółek notowanych na GPW w Warszawie najlepsze wyniki można było uzyskać, posługując się średnią ruchomą 10-sesyjną, która była najkrótszą spośród wszystkich długości średnich testowanych przez autora. Z kolei Filar i Kąkol (2013) udowodnili wyższą skuteczność średnich krótkoterminowych niż długoterminowych dla indeksu WIG20 oraz wybranych, wchodzących w jego skład.

Po drugie, najlepsze wyniki inwestycyjne można było osiągnąc przy zastosowaniu średniej ruchomej WMA, która w przeprowadzonych pod względem wielu kategorii rankingach plasowała się nieznacznie przed średnią SMA. Obie średnie znacznie wyprzedzały w tych samych rankingach średnią EMA. Dla średnich EMA i SMA otrzymane rezultaty potwierdzają badania Hochheimera (1978), a są niezgodne z tym, co stwierdził w swojej pracy Appel (2005). Uzyskane w niniejszym artykule rezultaty częściowo są zgodne z wnioskami, jakie wysnuła Górska (2008). Jej zdaniem najbardziej skuteczną dla indeksu WIG-Chemia okazała się średnia ruchoma EMA, co jest sprzeczne $\mathrm{z}$ wynikami opisanymi w tym opracowaniu. Z kolei najwyższy zysk dla indeksu WIG-Spożywczy według Górskiej (2008) przyniosła SMA, co jest zgodne z wynikami zamieszczonymi w niniejszym opracowaniu. Należy jednak pamiętać, że autorka bazowała jedynie na średnich SMA i EMA oraz o tym, że w międzyczasie (tj. od 2008 r. do 31 marca 2019 r.) zmianie uległa nazwa indeksu (z WIG-Chemia na WIG-Chemia i surowce) oraz jego skład.

Ograniczeniem przeprowadzonego badania są różne horyzonty inwestycyjne dla poszczególnych walorów. $Z$ jednej strony przyjęcie długiego horyzontu inwestycyjnego (5000 sesji) ma uwiarygodnić uzyskiwane wyniki badań, eliminując z nich pierwiastek przypadkowości, lecz z drugiej nie jest możliwe przeanalizowanie tak dużej liczby walorów (404) w tak długich interwałach czasowych, co utrudnia porównanie uzyskanych wyników. 
Przeprowadzone badania powinny w przyszłości objąć także inne klasy aktywów (np. surowce i towary, commodities) oraz uwzględnić inne, bardziej złożone miary stabilności systemów transakcyjnych. W przypadku surowców i towarów badanie powinno być przeprowadzone z podziałem na surowce energetyczne, metale, surowce pochodzenia roślinnego i pochodzenia zwierzęcego oraz inne. Do analizy stabilności systemów transakcyjnych można zastosować m.in. współczynnik Calmara, Sterlinga, Ulcera, Omega czy Sortino.

\section{Bibliografia}

Achelis, S. (1998). Analiza techniczna od A do Z. Warszawa: Wydawnictwo LT\&P.

Appel, G. (2005). Technical Analysis Power Tools for Active Investors. New York: Prentice Hall Publishing. Aronson, D. (2007). Evidence-based Technical Analysis. Hoboken: John Wiley \& Sons.

Bolton, J., Boetticher, S. von (2015). Momentum Trading on the Johannesburg Stock Exchange after the Global Financial Crisis. Procedia Economics and Finance, 24. doi:10.1016/S2212-5671(15)00619-X

Brock, W., Lakonishok, H., LeBaron, B. (1992). Simple Technical Trading Rules and the Stochastic Properties of Stock Returns. Journal of Finance, 47(5). doi:10.1111/j.1540-6261.1992.tb04681.x

Czuba, M., Kaszuba, B. (2009). Porównanie efektów stosowania średnich ruchomych w analizie finansowych szeregów czasowych polskiego rynku akcji. Prace Naukowe Uniwersytetu Ekonomicznego we Wroctawiu. Nauki o Finansach, (75).

Faber, M. (2007). A Quantitative Approach to Tactical Asset Allocation. Journal of Wealth Management, 9(4). doi:10.3905/jwm.2007.674809

Fifiled, S., Power, D., Knipe, D. (2008). The performance of moving average rules in emerging stock markets. Applied Financial Economics, 18(19). doi:10.1080/09603100701720302

Filar, W., Kąkol, W. (2013). Znaczenie średnich ruchomym w podejmowaniu decyzji inwestycyjnych na giełdzie. Modern Management Review, 18(20).

Gatley, E. (1999). Cena i czas. Zarys metod analizy technicznej. Warszawa: WIG-PRESS.

Górska, A. (2008). Zastosowanie narzędzi analizy technicznej w bezpośrednim i pośrednim inwestowaniu w towary. Zeszyty Naukowe SGGW. Ekonomika i Organizacja Gospodarki Żywności, (71).

Górska, A. (2011). Wykorzystanie strategii inwestycyjnych opartych na analizie technicznej do handlu towarami z WGT SA. Zeszyty Naukowe SGGW. Problemy Rolnictwa Światowego, (11).

Grebenkov, D., Serror, J. (2014). Following a trend with an exponential moving average: Analytical results for a Gaussian model. Physica A: Statistical Mechanics and its Applications, 394. doi:10.1016/j.physa.2013.10.007

Gwilym, O., Clare, A., Seaton, J., Thomas, S. (2010). Price and Momentum as Robust Tactical Approaches to Global Equity Investing. Journal of Investing, 19(3). doi:10.3905/joi.2010.19.3.080

Hochheimer, C. (1978). Computers Can Help You to Trade the Futures Markets. New York: Commodity Yearbook, Commodity Research Bureau.

Juszczuk, P., Kozak, J. (2016). Paradygmat programowania proceduralnego w procesie budowy systemów automatycznych bazujących na średnich kroczących. Studia Informatica Pomerania, (39).

Katsanos, M. (2009). Intermarket Trading Strategies. Chichester: Wiley \& Sons.

Kaufman, P. (1978). Commodity Trading Systems and Methods. New York: John Wiley \& Sons.

Kaufman, P. (2013). Trading Systems and Methods. New York: John Wiley \& Sons.

Keltner, C. (1960). How to Make Money in Commodities. Kansas City: The Keltner Statistical Service.

Kilgallen, T. (2012). Testing the Simple Moving Average across Commodities, Global Stock Indices, and Currencies. Journal of Wealth Management, 15(1). doi:10.3905/jwm.2012.15.1.082

LeBeau, C., Lucas, D. (2016). Komputerowa analiza rynków terminowych. Warszawa: WIG-PRESS. 
Letkowski, D. (2014). Wykorzystanie średnich ruchomych w analizie inwestycji giełdowych - dobór modelu i długość próby. Acta Universitatis Lodziensis. Folia Oeconomica, (2).

Mastalerz-Kodzis, A. (2013). Zastosowanie funkcji Höldera w modelu FRAMA. Studia Ekonomiczne, (159).

Mitra, S. (2011). Usefulness of Moving Average Based Trading Rules in India. International Journal of Business and Management, 6(7). doi:10.5539/ijbm.v6n7p199

Moskowitz, T., Ooi, Y., Pedersen, L. (2012). Time series momentum. Journal of Financial Economics, 104. Murphy, J. (1995). Analiza techniczna. Warszawa: WIG-PRESS.

Nisson, S. (1996). Świece i inne japońskie metody analizowania wykresów. Warszawa: WIG-PRESS.

Nowakowski, J., Borowski, K. (2005). Zastosowanie teorii Carolana i Fischera na rynku kapitatowym. Warszawa: Difin.

Pring, M. (1998). Podstawy analizy technicznej. Warszawa: WIG-PRESS.

Raudys, A., Pabarskaite, Z. (2018). Optimizing the smoothness and accuracy of moving average for stock price data. Technological and Economic Development of Economy, 24(3).

Salamaga, P. (2013). Zastosowanie metody średniej kroczącej do badania zyskowności inwestycji na polskim rynku kapitałowym. Prace Naukowe Uniwersytetu Ekonomicznego we Wrocławiu. Nauki o Finansach, (323).

Skalrew, A. (1980). Technical of Professional Commodity Chart Analysis. New York: Commodity Research Bureau.

Tarczyński, W., Łuniewska, M. (2004). Dywersyfikacja ryzyka na polskim rynku kapitałowym. Warszawa: Wydawnictwo Placet.

Witkowska, D., Matuszewska, A., Kompa, K. (2008). Wprowadzenie do ekonometrii dynamicznej i finansowej. Warszawa: Wydawnictwo SGGW.

Zalewski, G. (2001). Kontrakty terminowe w praktyce. Warszawa: WIG-PRESS. 